\title{
ІСТОРІЯ УКРАїНИ
}

УдК 94 (100): 271.3: 262.146 (477.83) "13/14"

DOI: https://doi.org/10.31652/2411-2143-2021-37-9-16

\author{
Роман Кузьмин \\ Національний університет «Львівська політехніка» \\ кандидат історичних наук (Україна) \\ e-mail: kuzminroman7@gmail.com \\ ORCID: http://orcid.org/0000-0001-7042-9310 \\ Scopus ID: 57211123727
}

\section{Орден домініканців на землях Галицько-Волинського князівства (Руського королівства) (на прикладі Львова XIII-XIV ст.): між легендою та історією}

\begin{abstract}
Анотація. Метою публікації є з'ясувати обставини появи католицького чернечого ордену домініканців на території Галицько-Волинського князівства (Руського королівства) та його зусилля щодо закріпленню на цих землях. Методологічну основу дослідження складають загальнонаукові методи порівняння та аналізу. Під час підготовки до публікації провідними методами стали історично-порівняльний, синхронний та ретроспективний. Використання згаданих наукових методів дозволило проаналізувати джерела та дійти висновків щодо наукової проблеми. Наукова новизна дослідження полягає в тому, що дослідник здійснив спробу аналізу доступних джерел та історіографрічних наративів щодо появи ордену домініканців у Галицько-Волинському князівстві загалом та у Львові зокрема. Висновки. Поява ордену домініканців у XIII-XIV cm. на теренах Руського королівства була не випадковою. Місії духовного ордену слугували проникненню католицького духовенства, організації осередків місіонерської діяльності та були підготовкою до заснування постійної церковної адміністрації на землях Галицько-Волинського князівства. Розширення мережі осередків ордену тісно пов'язане зі зростанням урбаністичної мережі та посиленням міграційних процесів міського римо-католицького населення з німецьких та польських земель. Питання щодо віровизнання відігравало важливе значення у дипломатії галицько-волинських князів та польських королів цього періоду. Балансуючи між католицьким та "степовим» світом, князі Руського королівства вимушені йти на компроміси та надавати дозволи на заснування католицьких осередків на території Львова та інших міст. Орден домініканців активно сприяв проникненню католицизму та впливу Апостольського престолу в Римі на території Київської Русі.
\end{abstract}

Ключові слова: релігія, орден домініканців, Руське королівство, Львів, Польське королівство, Апостольський престол.

Постановка проблеми. Історія України в багатьох аспектах $\epsilon$ поліетнічною та полікультурною за своєю суттю та змістом. Фронтирний характер розташування українських земель зумовлює неминучість геополітичних, економічних, міграційних, культурних, релігійних контактів та взаємовпливів із сусідніми регіонами. Глибока вкоріненість релігійно-конфесійної свідомості в життя і побут народів епохи середньовіччя, які проживали на наших теренах, зумовлювали як унікальні приклади позитивної взаємодії, так і зразки релігійної і культурної нетерпимості, що $€$ характерним для всіх країн європейського континенту. Частиною цієї проблематики також $€$ історія появи та діяльності католицьких чернечих орденів на території України, якій присвячена наша публікація.

Аналіз джерел та останніх досліджень. Питання щодо появи католицьких чернечих орденів має давню традицію, але часто ставало заручником політичного мейнстріму свого часу. До одних з перших ранньомодерних хроністів, які торкалися проблематики домініканського ордену на території Галичини і Львова, належить Бартоломей Зіморович та Мартін Ґруневеґ' [Зіморович, 2002]. У характерній для свого часу манері вони переплітали легенди, чутки та реальні події у цікаву оповідь, проте вона потребує ретельної верифікації. Важливе значення має монументальний збірник документів «Vetera Monumenta Poloniae et Lithuaniae», в якому опубліковано документи із папського архіву в Римі, які не втратили свою актуальність й сьогодні. До окремої групи належать історики домініканського ордену, які мали духовний сан і долучилися до формування низки вкорінених легенд про домініканський орден в Галичині. Серед них варто виокремити Тому Піравского, Симона Окольського, Карла Вєтца та Петера Богмана, Яна Фіялека [Wietz, Bohman, 1848; Fijałek, 1925]. Польські дослідники з XIX ст. активно працюють над вивченням історії римо-католицької церкви на українських землях. Одним із патріархів цього 
напряму історичних досліджень безсумнівно є Владислав Абрагам, який опрацював значне коло першоджерел із церковної тематики [Abraham, 1904]. Тематику історії церкви Галичини та Львова вивчали Юзеф Скочек і Владислав Жила [Skoczek, 1928; Żyła, 1923]. Серед сучасних польських дослідників, які торкаються проблематики домініканців, слід виокремити Павела Краса, Мацея Мацєйовського та Едмунда Длуґопольського [Kras, 2013; Długopolski, 2009; Maciejowski, 2003].

Серед української історичної школи передусім варто згадати дослідників XIX ст. - Дениса Зубрицького та Ісидора Шараневича, які писали праці на джерелах [Зубрицький, 2011; Шараневич, 1886]. Зразком радянської історичної школи є праця Бориса Рамма, яка попри ідеологічну упередженість щодо церкви, базується на великому колі джерел дипломатичного характеру [Рамм, 1959]. Сучасних українських дослідників можна розділити за науковими інтересами: питання, пов'язані із проблемами архітектурних пам'яток та їхньою історією, вивчають Володимир Вуйцик, Микола Бандрівський та Микола Хмільовський [Вуйцик, 1991; Бандрівський, 2012; Хмільовський, 2009]. Проблеми політичної та династичної історії ГалицькоВолинського князівства досліджує Леонтій Войтович [Войтович, 2016]. Натомість історики Олександр Головко та Ілля Паршин зосередилися на контактах галицько-волинських князів із Римом [Головко, 2008; Паршин, 2017]. Ольга Козубська присвятила публікацію легенді про «королеву Констанцію» та ії протегування ордену домініканців [Козубська, 2007]. Історію вірменської громади Львова та Галичини ретельно вивчає Олександр Осіпян [Осіпян, 2014].

Мета статті. 3'ясувати обставини появи католицького чернечого ордену домініканців на території Галицько-Волинського князівства (Руського королівства) та його зусилля щодо закріплення на цих землях.

Виклад основного матеріалу. Розвиток міст у Центральній і Східній Європі спонукав до низки структурних змін у середньовічних соціумах. Одним з таких став феномен міських монастирів, які окрім духовного життя, брали активну участь у політичному, економічному соціальному та культурному житті міщан. Перелом XII-XIII ст., який супроводжувався демографічним ростом, економічним підйомом міст і виникненням університетів, спонукав до змін всередині католицької церкви. Набирає популярності течія про необхідність відновлення «первісної євангелічної простоти та бідності» [Spież, 2016 : 5].

За свідченням авторитетного польського дослідника Владислава Абрагама, з середини XIII ст. розпочинається епоха великих місіонерських виправ на територію Руського королівства, зі спробами заснування мережі католицьких церков, в яких брали активну участь чернечі ордени [Abraham, 1904 : 165].

Саме таку місію на себе взяли чернечі ордени, серед яких виокремлювалися «жебручі ордени» (мендикани) - францисканці (орден св. Франциска з Асизу) та домініканці (орден св. Домініка). Патрон домініканського ордену часто зображався із Євангелієм відкритим на словах Ісуса «Йдіть на цілий світ і навчайте» [Spież, 2016 : 8]. Девіз ордену - «словом і прикладом» (verbo et exemplo), спонукав до активної місіонерської діяльності. Тому ордени мендиканів взяли активну участь у місії поширення католицизму на нові терени - язичницькі, мусульманські та православні землі.

Ordo praedicatorum («орден проповідників»), який засновано 1215 р. Домініком де Гусманом, вже 22 грудня 1216 р. затверджений папою Гонорієм III [Kunasiewicz, 1876 : 2]. Ha землях Корони Польської ченці ордену з'явилися у 1223 р., коли їх до Кракова урочисто привів Гіацинт Яцек (Hiacyntus Jacek) Одровонж [Żyła, 1923 : 1]. Дядько Гіацинта - Іво Одровонж, який був єпископом Кракова, передав домініканцям костел св. Трійці і здійснив фундацію монастиря, який увійшов до угорської провінції ордену (Ordini praedicatorum). У 1228 р. засновано окрему польську провінцію домініканців, до якої входили монастирі у Празі, Вроцлаві, Ґданську, Судомирі, Камені-Поморському і Києві (до 1234 р.). Керівника ордену - ґвардіана, обирали на 3 роки, а генералів провінцій ордену - на 6 років [Wietz, Bohman, $1848: 212$ ]. Очолював її провінціал Ґерард, який був настоятелем монастиря у Кракові [Хмільовський, 2009 : 34]. Так, станом на середину XIII ст. мережа монастирів домініканського ордену охопила практично всі середньовічні європейські держави [Kras, 2013 : 14].

Поява самих орденів на території Львова та в Руському королівстві огорнута міфами та вкоріненою історіографічною традицією. За легендою істориків-домініканців, монастир ордену у Львові з'явився у відрізку 1222-1234 рр., коли св. Гіацинт, прямуючи із Кракова до Києва, заночував на території сучасного Львова і заклав у пущі костел і кляштор ордену. Тобто заснування ордену передувало заснуванню самого Львова як «міста в мурах».

За однією поширеною версією польської історіографії XIX - першої половини XX ст., одним із перших католицьких костелів на території міста Львова був «домініканський костел св. Івана Хрестителя», заснований близько 1250 р. [Kumor, 2001 : 50; Żyła, 1923 : 1; Поліщук, 2015]. Він мав слугувати для потреб переважно місцевих католиків і німецьких купців, які прибували зі сторони Торуня, Ґданська і Кракова, з якими львівські купці вели жваву торгівлю у XIII-XIV ст. 
[Осіпян, 2014 : 52]. За іншою версією цієї ж історіографічної традиції, храм Івана Хрестителя, що на місці майбутнього монастиря домініканців, також мав характер палацової каплиці дружини князя Лева Даниловича - угорської принцеси Констанції, доньки угорського короля Бели IV, де за однією з версій вона й була похована [Abraham, 1904 : 169,178; Skoczek, 1928 : 5; Бандрівський, $2012:$ 232].

Львівський хронікар XVII ст. Бартоломей Зіморович у творі «Leopolis Triplex» також повторює таку легенду, але помилково називав Констанцію не дружиною, а мачухою Лева Даниловича. Зокрема, він зазначав, що князь відступив Констанції свій палац: «До святих покоїв Констанції у великій кількості сходилися натовпи новонавернених...Однак на першому місці серед її відвідувачів були римо-католики, і в першу чергу проповідники закону благання, керівники її сповіді з ордену святого Домініка і святого Франциска, прислані на Русь для виконання святих обрядів. Довкола них справді юрмилися у незліченній кількості люди обох статей, яких Констанція навіть (забезпечувала) приданим і домашніми речами, давала на відкуп і звільняла полонених із скіфських пазурів. Під заслоном цієї героїчної (жінки) вони почали вже там будувати святі добродійні доми, а собі гнізда, що не заборонялося Левом через його зайнятість розбудовою міста» [Зіморович, 2002 : 54]. Ранньомодерний хронікар зосередився на демонстрації католицької присутності від часу заснування Львова, протиставляючи ії̈ «дикості» православних князів Руського королівства [Козубська, 2007 : 103-104].

У XVII ст. легенду також підкріпили львівський канонік Тома Піравскій та історик домініканського ордену Симон Окольській, які закріпили в історичному наративі заснування кляштору домініканського ордену з моменту дарування князем Левом Даниловичем палацу для потреб ордену, здійснене на прохання «королеви Галичини» («regina Haliciae») Констанції. Саме з монастирем пов'язувалося місце поховання покровительки «перших домініканців» [Козубська, 2007 : 101-102]. Інший ранньомодерний автор Пйотр Яцек Прущ у творі «Forteca monarchów i całego Królestwa Polskiego duchowna...» стверджував, що Констанція 9 квітня 1276 р. була похована у костелі Божого тіла домініканського ордену [Зіморович, 2002 : 194].

Архіваріус домініканського монастиря у Львові кінця XVI ст. Мартін Ґруневеґ стверджував, що князь надав руську церкву апостолів Петра і Павла ордену домініканців, щоб вони добудували до неї монастирські приміщення. Первісна церква була розширена - стара частина (руська) стала пресвітерієм Петра і Павла, а нова - названа в честь Божого тіла (Тіла Христового). 3 XVII ст. увесь комплекс монастиря носив назву Божого тіла [Хмільовський, 2012 : 220].

На думку історика В. Абрагама, поряд із костелом Івана Хрестителя мав знаходитися головний осередок ордену домініканців у Руському королівстві [Abraham, $1904: 169]$. У 1277 р. генеральна капітула домініканців у Бордо дала дозвіл на створення двох нових монастирів ордену в польській провінції, поряд із Руським королівством («versus Russiam») [Хмільовський, 2009 : 36]. Тому, В. Абрагама вважав, що в цей час засновано конвент руської провінції ордену, а в 1297 р. за межами міських мурів Львова повстав кляштор домініканців св. Яна (Яцька) (за іншими даними він з'явився лишень у часи Казимира III), яким у XIV ст. володіли вірменські василіани, які були в унії з Римом [Sperka, 2018 : 156]. За гіпотезою, цей домініканський монастир припинив існування перед 1396 р., оскільки у другій половині XIII ст. домініканці втрачають свій вплив у Галичині [Abraham, $1904: 169-175]$.

Дослідники давньоруської спадщини Львова Денис Зубрицький та Ісидор Шараневич вважали, що домініканський монастир Божого тіла (Тіла Христового) засновано на місці православної церкви св. Покрови (Різдва Пресвятої Богородиці) [Зубрицький, 2011 : 112; Шараневич, 1886 : 1-12; Бандрівський, 2012 : 234]. За гіпотезою сучасного українського дослідника Миколи Хмільовського, домініканський монастир Божого тіла (Тіла Христового) засновано на місці православного монастиря Петра і Павла, закладеного ще князем Левом Даниловичем. На думку дослідника, поряд знаходився княжий двір, а із заснуванням православної Галицької митрополії, збудовано ще й катедральний собор. Тому, обґрунтував думку, що на цьому місці домініканські ченці були не першими - до них тут існував монастир православного «василіанського» духовенства («S. Basilii Monachorum») [Хмільовський, 2009 : 34; Хмільовський, 2012 : 178].

Натомість інший дослідник - Микола Бандрівський - вважає, що це був храм св. Йоана Хрестителя. Він наводить слова І. Мицька, що домініканці «церков митрополію взявши, вчинили Божім Тілом», тобто православний катедральний храм княжого Львова був забраний орденом у XIV ст. і на його місці влаштовано костел і монастир Божого тіла [Бандрівський, 2012 : 216-220].

Сучасні дослідники критично ставляться до питання часу заснування храму св. Івана Хрестителя на площі Старий ринок у Львові XIII ст., як і до міфу про появу домініканського ордену у Львові. За свідченням авторитетної дослідниці середньовічного Львова Ольги Козубської, міф про патронат княгині Констанції над домініканським монастирем у Львові 3 
XVII ст. активно поширювали самі ченці ордену, зокрема під час судових процесів [Вуйцик, 1991

: 12; Козубська, $2007: 100,105]$.

Натомість храм св. Івана Хрестителя вперше згадується в архівних джерелах 1371 р. і швидше за все належав львівським вірменам. Особливості кам'яної кладки та стрільчасті вікна свідчать про його спорудження у другій половині XIV - початку XV ст. [Бандрівський, 2012 : 222; Козубська, $2007: 105]$. Також дослідники вказують на те, що немає достовірних джерел для твердження про появу костелів чи монастирів домініканського ордену в Руському королівстві до середини XIV ст. Загалом дослідники Руського королівства кінця XIII-XIV ст., услід за Михайлом Грушевським, говорять про «кіммерійську пітьму» у вивченні цього періоду регіону, через критичний брак джерел [Паршин, 2017 : 318].

Варто зауважити про роль, яку надавав папський престол жебручим орденам (мендиканам) у поширенні католицизму на сході Європи. Статут ордену домініканців накладав на ченців обітницю апостольського вбогого способу життя (vita evangelica) і проповідування Слова Божого [Головко, 2008 : 68; Kras, 2013 : 13]. До того ж в ордені існувала жорстка централізована структура, яка робила 3 нього зразковий інструмент для поширення католицизму. Життя ченців, заснованого на статуті св. Домініка, жорстко регламентувало місіонерську діяльність братії. Особливістю орденів мендиканів був їхній тісний зв'язок із містами і активна залученість у суспільне життя міських осередків, де з'являлися ченці [Kłoczowski, $1953: 48]$.

Місії домініканців і фрранцисканців проникали до Руського королівства та решти земель Русі двома шляхами - через Угорщину та Східну Пруссію [Abraham, 1904 : 170]. Одна з активних домініканських місій, відправлених до Русі в 1222-1224рр. на чолі з Яцеком (Гіацинтом) Одровонжем, отримала від київського князя Володимира Рюриковича дозвіл на заснування монастиря Діви Марії біля Києва. Його супутники - Бернард і Яків Римлянин - висвячені папою Григорієм IX на єпископів Русі. Чотирьохрічне перебування Гіацинта Одровонжа у Києві закінчилося вигнанням місії з Києва. Загалом Гіацинт Одровонж став легендарною фігурою, зокрема здійснив низку чудес і був канонізований католицькою церквою, і долучений до лику святих [Рамм, 1959 : 141]. 31230 р. орден домініканців отримує повне сприяння Апостольського престолу в місіонерській діяльності в Пруссії та Лівонії. Так, у 1234 р. єпископом у Ризі призначено домініканця Генріха [Рамм, 1959 : 120]. Так, це відкрило можливості для надсилання місій ордену ще далі на схід і південь. Зокрема, в 1236 р. з Угорщини вирушив домініканець Юліан, який дійшов до «мордванів» (мордва) на р. Волзі. А в 1240-х рр. домініканська місія, на чолі з Ансельмом Асцеліною, була відправлена в Іран, де вела переговори 3 монгольським ханом Байду [Головко, 2008 : 70; Рамм, $1959: 142,153]$.

До того ж під час переговорів князя Данила Романовича із папою Інокентієм IV, особистим духівником якого був фрранцисканець Ніколо де Курбіо (Ніколо де Кальві), щодо прийняття корони і переходу «під покровительство св. Петра» згадується про місію галицького князя до Риму, в якій брали участь абат монастиря св. Данила Григорій і два домініканські ченці - «брат Олексій та Г.». Останнього інколи індентифрікують як Гіацинта (Яцька) Одровонжа. Обидва перед тим були із проповідницькою місією у Чехії [Войтович, 2016 : 24].

Активній місіонерській діяльності орденів домініканців і фрранцисканців на землях Руського королівства мало сприяти утворення в XIII ст. спільної автономної конгрегації «Societas fratrum peregrinantium propter Christum inter Gentes» (Товариство пілігримів Христа між народами). Конгрегація мала власного вікарія та користувалася досить широкою незалежністю від місцевих єпископів та світських очільників. Ченців до місій конгрегації набирали з обох орденів. Окрім Руського королівства та земель колишньої Київської Русі, домініканське крило конгрегації активно розгорнуло діяльність серед генуезьких колоній у Криму і басейні Чорного моря [Abraham, 1904 : 175-177; Fijałek, $1925: 5$; Kumor, $2001: 50]$.

На початку XIV ст. активізувалося проникнення католицьких орденів на терени Руського королівства. Управлінням місій на Русі намагалися керувати осередки на території Корони Польської, з огляду на те, що на початку XIV ст. ордену домініканців активно сприяв особисто польський король Владислав I Локєтек. Натомість князь Юрій I Львович (1252-1308) у 1303 р. заснував окрему Галицьку митрополію, яка мала протистояти наступу католицької церкви на землі Руського королівства [Abraham, 1904 : 173; Паршин, 2017 : 320].

Папа Іоан XXII (1316-1334) був активним ініціатором проникнення представників орденів мендиканів із Польського і Угорського королівств на територію православних князівств Київської Русі, язичницьких Литви і Золотої Орди аж до Китаю включно [Długopolski, 2009 : 213]. Саме він у 1317 р. видав лист представникові «короля Польщі» Владислава Локєтка єпископу Божиславу, адресований «руським княжатам», очевидно до галицьких княжичів-братів Андрія та Лева, в якому закликав останніх полишити «схизму» та навернутися на «дорогу світла», адже такою $є$ католицька церква. Вже наступного 1318 р. папа своєю булою назначив трьох нунціївколекторів, для збору заборгованих церковних податків, зокрема й з «руської провінції». 
Прикметно, що єпископ Божислав, який представляв польського короля перед папою в Авіньйоні, помер та був похований в церкві ордену домініканців, що свідчить про їхній вплив на польського єпископа та загалом польські справи при Апостольському престолі [Długopolski, 2009 : 208-210].

Також папа Іоан XXII у листі до краківського єпископа Іоана, краківського князя та інших вельмож від 01 травня 1318 р. призначив монахів орденів мендиканів інквізиторами (inquisitors haereticae): домініканців - Колду і Переґрина з Ополя (Coldam et Peregrinum Oppolienses Predicatorum) інквізиторами у Кракові, для боротьби із релігійними течіями бегардів та бегінок, які виводили своє коріння із жебручих монаших орденів [Maciejowski, 2003 : 103; Vetera Monumenta Poloniae et Lithuaniae, 1860 : 137].

У 1323 р. після загибелі князів Андрія та Лева II польський король Владислав Локєтко вирішив скористатися відсутністю легітимних спадкоємців для Галицько-Волинського князівства і просив у Риму оголосити хрестовий похід проти татар, щоб розширити межі впливу католицької церкви та опанувати «землі схизматиків» [Długopolski, 2009 : 251]. Наслідком військовополітичного тиску польського короля стало обрання останнього князя Руського королівства Юрія (Болеслава) II Тройденовича, який походив із Мазовії, а його мати Марія Галицька була донькою галицько-волинського князя Юрія I (1301-1315).

Князь Юрій II, попри перехід у східний обряд християнства, активно сприяв проникненню домініканського ордену на територію Руського королівства. Сам князь після одруження на дочці литовського князя Гедеміна, швидко охрестив іï за латинським обрядом [Abraham, 1904 : 192194]. Папа Іоан XXII у 1331 р. дозволив польському провінціалу заснувати конвент домініканців у Жмигороді, на кордоні краківської єпархії «з причини сусідства схизматиків, заради їх спасіння та з метою навчання їх католицької віри» [Хмільовський, 2009 : 36]. Сприяння латинізації і щедре дарування майна було однією із причин насильницької смерті Юрія II та його дружини, яка стала сигналом для хвилі антикатолицьких виступів у Руському королівстві та приводом для походу Казимира III у 1340 p.

Так, діяльність місій ордену домініканців у XIII-XIV ст. на теренах Руського королівства слугувала проникненню католицького духовенства, організації осередків місіонерської діяльності та була підготовкою до заснування постійної церковної адміністрації на цих землях. Питання про віровизнання відігравало важливе значення у дипломатії галицько-волинських князів та польських королів згаданого періоду. Балансуючи між католицьким та «степовим» світом, князі Руського королівства були вимушені йти на компроміси та надавати дозволи на заснування римо-католицьких осередків на території Львова та інших міст. Орден домініканців активно сприяв проникненню католицизму та впливу Апостольського престолу в Римі на території Київської Русі.

Подяка. Висловлюю подяку членам редколегії журналу за консультації, надані під час підготовки статті до друку.

Фінансування. Автор не отримав фрінансової підтримки для дослідження, авторства та / або публікації цієї статті.

\section{Джерела та література:}

Бандрівський, М. (2012). До проблеми локалізації «МЕГАЛЄ ЕККЛЄЗІЯ» руських князів у Львові. Матеріали і дослідження з археології Прикарпаття і Волині. Вип. 16. С. 21-238.

Войтович, Л. (2016). Король Данило Романович: давні і модерні напрями фальсифікації портрету. Король Данило Романович: культурна і державотворча спадщина його доби / ред. М. Бевз, Ю. Лукомський. Львів, Вид-во «Растр-7». С. 12-35.

Вуйцик, В. С. (1991). Державний історико-культурний заповідник у Львові. Львів, Каменяр. $175 \mathrm{c.}$.

Головко, О. (2008). Держава Романовичів у східноєвропейській політиці римської курії 40-50-х років XIII ст. Княжа доба: історія і культура. Львів, Вип. 2. С. 67-84.

Зіморович, Б. (2002). Потрійний Львів: Leopolis Triplex. Львів, Центр Європи, 224 с.

Зубрицький, Д. (2011). Хроніка Ставропігійського братства. Львів. 408 с.

Козубська, О. (2007). Львівська легенда княгині Констанції. Княжа доба: історія і культура / ред. Я. Ісаєвич. Львів, Інститут українознавства ім. І. Крип'якевича НАН України. Вип. 1. С. 100 105.

Осіпян, О. (2014). Історичні уявлення та їх використання у соціальних конфліктах: звернення до далекого минулого у судовій тяжбі міського магістрату з вірменською громадою у Львові у 1578 р. Ранньомодерна Україна на перехресті цивілізацій, культур, держав та регіонів / ред. В. Смолій. Київ, Інститут історії України НАН України. С.41-56.

Паршин, І. (2017). Чи було папське посольство до Галицько-Волинської держави на початку XIV століття? Княжа доба: історія і культура. Львів. Вип. 11 (Княжий Львів 1256-2016). С. 318325. 
Поліщук, Н. (2015). Храм Св. Івана Хрестителя у Львові та ікона Львівської Богородиці. Режим доступу: https://risu.org.ua/ua/relig_tourism/religious_region/59156/ .

Рамм, Б. Я. (1959). Папство и Русь в X-XV веках. Москва-Ленинград, АН СССР. 284 с.

Хмільовський, М. (2009). Де розміщувалася у Львові руська церква апостолів Петра і Павла? Апологет, № 1-4 (16-19). Матеріали I Міжнародної наукової конференції м. Львів, 23-24 листопада 2009 р. С. 34-42. Режим доступу: https://core.ac.uk/download/pdf/32981913.pdf .

Хмільовський, М. (2009). До питання про палати князя Лева Даниловича у Львові // Апологет. Матеріали V Міжнародної наукової конференції «Християнська сакральна традиція: віра, духовність, мистецтво» м. Львів, 23-24 листопада 2012 р. С. 178-182.

Шараневич, І. (1886). Історіческій очерк о Ставропигійской церкви Успенія Пр. Богодіци во Львове // Юбилейное издание в память 300-летия основания Ставропигийского братства. Львов, Ставропигийский институт, Т. 1. С.1-12.

Abraham, W. (1904). Powstanie organizacyi kościoła łacińskiego na Rusi. Lwów, Towarzystwo dla popierania nauki polskiej. T. $1.418 \mathrm{~s}$.

Długopolski, E. (2009). Władysław Łokietek na tle swoich czasów. Kraków, TAiWPN UNIVERSITAS. $390 \mathrm{~s}$.

Fijałek, J. (1925). Dwaj dominikanie krakowscy: Jan Biskupiec i Jan Falkenber. Lwów, Zakład Narodowy im. Ossolińskich. $82 \mathrm{~s}$.

Kłoczowski, J. (1953). Reforma polskiej prowincji dominikańskiej w XV-XVI w. Roczniki Humanistyczne, 4, S. 45-92.

Kras, P. (2013). Średniowieczna inkwizycja i Zakon Braci Kaznodziejów. Zarys problematyki badawczej. Caldwell Ames C. Inkwizycja i Bracia św. Dominika. Słuszne prześladowanie. Poznań, Wydawnictwo «W drodze». S. 7-35.

Kumor, B. (2001). Historia Kościoła. Lublin, Katolicki Uniwersytet Lubelski. Cz. IV. 252 s.

Kunasiewicz, S. (1876). Przewodnik po kościele Bożego Ciała OO. Dominikanów we Lwowie. Lwów, I Związkowa Drukarnia. $215 \mathrm{~s}$.

Maciejowski, M. (2003). Ostatnie lata biskupa krakowskiego Jana Muskaty (1317-1320). Biskupi, lennicy, żeglarze. Gdańskie studia z dziejów średniowiecza, red. B. Śliwiński. № 9, Gdańsk. S. 93112.

Skoczek, J. (1928). Ze studjów nad średniowiecznym Lwowem. Lwów, I Związkowa drukarnia we Lwowie. (Pamiętnik Historyczno-prawny / red. P.Dąbkowskiego. T.VI, Zesz.3). $113 \mathrm{~s}$.

Sperka, J. (2018). Książę Władysław Opolczyk wobec Lwowa. Княжа доба: історія і культура / ред. В. Александрович. Львів, Вип. 12. S.113-160.

Spież, J.A. (2016). Święty Dominik. Poznań, Wydawnictwo «W drodze», 2016. 104 s.

Vetera Monumenta Poloniae et Lithuaniae (1860), ed. A. Theiner. Roma, Typis Vaticanis, 1860. T. I (1217-1409). $788 \mathrm{p}$.

Żyła, W. (1923). Kościół i klasztor Dominikanów we Lwowie. Lwów, Drukarnia L. Wiśniewskiego. $76 \mathrm{~s}$. Wietz, J. K., Bohman P. (1848). Rys historyczny zgromadzeń zakonnych obojej płci wraz z rycerskiemi zakonami i orderami państw. Warszawa, Drukarnia księży pijarów. $258 \mathrm{~s}$.

\title{
Роман Кузьмин
}

Национальный университет «Львовская политехника» кандидат исторических наук (Украина)

\section{Орден доминиканцев на землях \\ Галицко-Волынского княжества (Русского королевства) (на примере Львова XIII-XIV вв.): между легендой и историей}

\begin{abstract}
Аннотация. Целью статьи является выяснить обстоятельства появления римскокатолического монашеского ордена доминиканцев на территории Галицко-Волынского княжества (Русского королевства) и его усилия по закреплению на этих землях. Методологическую основу исследования составляют общенаучные методы сравнения и анализа. Во время подготовки к публикации ведущими методами были историкосравнительный, синхронный и ретроспективный. Использование упомянутых научных методов позволило проанализировать источники и сделать выводы о изучаемой проблеме. Научная новизна исследования заключается в том, что исследователь предпринял попытку анализа доступных источников и историографических нарративов о появлении ордена доминиканцев в Галицко-Волынском княжестве в целом и во Львове в частности. Выводы. Появление ордена доминиканцев в XIII-XIV вв. на территории Русского королевства было не случайным. Миссии духовного ордена служили проникновению римскокатолического духовенства, учреждению ячеек миссионерской деятельности и были подготовкой к учреждению постоянной церковной администрации на землях Галицко-
\end{abstract}


Волынского княжества. Расширение сети ячеек ордена тесно связано с ростом урбанистической сети и усилением миграционных процессов городского католического населения из немецких и польских земель. Вопрос вероисповедования играл важную роль в дипломатии галицко-волынских князей и польских королей этого периода. Балансируя между католическим и «степным» мирами, князья Русского королевства были вынуждены идти на компромиссы и предоставлять разрешения на учреждение католических ячеек на территории Львова и других городов. Орден доминиканцев активно вел перед проникновения католицизма и влияния Апостольского престола в Риме на территории Киевской Руси.

Ключевые слова: религия, орден доминиканцев, Русское королевство, Львов, Польское королевство, Апостольский престол.

\author{
Roman Ya. Kuzmyn \\ Lviv Polytechnic «National University» \\ $\mathrm{PhD}$ (History) (Ukraine)
}

\title{
Order of the Dominicans on the Lands of the Galicia-Volyn Principality (Russian Kingdom) (the case of Lviv $13^{\text {th }}-14^{\text {th }}$ centuries): Between Legend and History
}

\begin{abstract}
The purpose of the publication is to find out the circumstances of the emergence of the Roman Catholic Dominican monastic order on the territory of the Galicia-Volyn principality (Russian Kingdom) and its efforts to consolidate in these lands. General scientific methods (comparison, analysis) are used as a research methodology. In preparation for publication, the leading methods were historical-comparative, synchronous and retrospective. The use of these scientific methods made it possible to analyze the sources and draw conclusions about the scientific problem. The scientific novelty of the study is that the researcher attempted to analyze available sources and formed historiographical narratives about the emergence of the Dominican Order in the Galicia-Volyn principality in general and in Lviv in particular. Conclusions. The emergence of the Dominican Order in the 13-th $-14^{-t h}$ centuries in the territory of the $n$ kingdom was not accidental. The missions of the spiritual order served for the penetration of the Roman Catholic clergy, the establishment of missionary centers and were preparation for the establishment of a permanent church administration in the lands of the Galicia-Volyn principality. The expansion of the Order's network was closely linked to the growth of the urban network and the intensification of the migration processes of the urban Roman Catholic population from German and Polish lands. The issue of religion played an important role in the diplomacy of the Galician-Volyn princes and Polish kings of this period. Balancing between the Catholic and "steppe" worlds, the princes of the Russian kingdom were forced to compromise and give permission for the establishment of Roman Catholic centers in Lviv and other cities. The Dominican Order actively led the penetration of Catholicism and the influence of the Apostolic See in Rome on the territory of Kyiv Rus.
\end{abstract} See.

Key words: religion, Order of Dominicans, Rusian Kingdom, Lviv, Kingdom of Poland, Holy

\section{References:}

Abraham, W. (1904). Powstanie organizacyi kościoła łacińskiego na Rusi. Lwów, Towarzystwo dla popierania nauki polskiej. T.1. $418 \mathrm{~s}$.

Bandrivskiy, M. (2012). Do problemy lokallzatsiyi «MEGALE EKKLEZIYa» ruskyh knyaziv u Lvovi. Materialy i doslidzhennya z arheologiyi Prykarpattya i Volyny. 16. 216-238. [in Ukrainian].

Długopolski, E. (2009). Władysław Łokietek na tle swoich czasów. Kraków, TAiWPN UNIVERSITAS. $390 \mathrm{~s}$.

Fijałek, J. (1925). Dwaj dominikanie krakowscy: Jan Biskupiec i Jan Falkenber. Lwów, Zakład Narodowy im. Ossolińskich. $82 \mathrm{~s}$.

Golovko, O. (2008). Derzhava Romanovychiv u shidno-evropeyskiy politytsi rymskoyi kuriyi 40-50-h rokiv XIII st. Knyazha doba: Istoriya $i$ kultura. Lviv, 2. 67-84. [in Ukrainian].

Hmilovskyi, M. (2009). De rozmischuvalasya u Lvovi ruska tserkva apostoliv Petra i Pavla? Apologet, № 1-4 (16-19). Materialy I Mizhnarodnoyi naukovoyi konferentsiyi m. Lviv, 23-24 lystopada 2009 r. 34-42. Elektronnyi resurs: https://core.ac.uk/download/pdf/32981913.pdf [in Ukrainian].

Hmilovskyi, M. (2009). Do pytannya pro palaty knyazya Leva Danylovycha u Lvovi. Apologet. Materialy V Mizhnarodnoyi naukovoyi konferentsiyi «Hrystyyianska sakralna tradytsiya: vira, duhovnist, mystetstvo» m. Lviv, 23-24 lystopada 2012 r. 178-182. [in Ukrainian].

https://risu.org.ua/ua/relig_tourism/religious_region/59156/[in Ukrainian].

Kłoczowski, J. (1953). Reforma polskiej prowincji dominikańskiej w XV-XVI w. Roczniki Humanistyczne, 4, 45-92. 
Kozubska, O. (2007). Lvivska legenda knyagyni Konstantsiyi. Knyazha doba: Istoriya $i$ kultura / red. Ya. Isaevych. Lviv, Instytut ukrayinoznavstva im. I.Kryp'yakevycha NAN Ukrayiny. 1. 100-105. [in Ukrainian].

Kras, P. (2013). Średniowieczna inkwizycja i Zakon Braci Kaznodziejów. Zarys problematyki badawczej. Caldwell Ames C. Inkwizycja i Bracia św. Dominika. Słuszne prześladowanie. Poznań, Wydawnictwo «W drodze». 7-35.

Kumor, B. (2001). Historia Kościoła. Lublin, Katolicki Uniwersytet Lubelski. Cz. IV. 252 s.

Kunasiewicz, S. (1876). Przewodnik po kościele Bożego Ciała OO. Dominikanów we Lwowie. Lwów, I Związkowa Drukarnia. $215 \mathrm{~s}$.

Maciejowski, M. (2003). Ostatnie lata biskupa krakowskiego Jana Muskaty (1317-1320). Biskupi, lennicy, żeglarze. Gdańskie studia z dziejów średniowiecza, red. B. Śliwiński. 9, Gdańsk. 93-112.

Osipyan, O. (2014). Istorychni uyavlennya ta yih vykorystannya u sotsialnyh konfliktah: zvernennya do dalekogo mynulogo u sudoviy tyazhbi miskogo magistratu $\mathrm{z}$ virmenskoyu gromadoyu u Lvovi u 1578 r. Rannomoderna Ukrayina na perehresti tsivilizatsiy, kultur, derzhav ta regioniv / red. V. Smoliy. Kiyiv, Institut Istoriyi Ukrayini NAN Ukrayini. 41-56. [in Ukrainian].

Parshin, I. (2017). Chy bulo papske posolstvo do Galytsko-Volynskoyi derzhavy na pochatku XIV stolittya? Knyiazha doba: Istoriya i kultura. Lviv. 11 (Knyiazhyi Lviv 1256-2016). 318-325. [in Ukrainian].

Polischuk, N. (2015). Hram Sv. Ivana Hrestytelya u Lvovi ta ikona Lvivskoyi Bogorodytsi. Elektronnyi resurs:

Ramm, B. Ya. (1959). Papstvo i Rus $v$ X-XV vekah. Moskva-Leningrad, AN SSSR. 284 s. [in Russian].

Skoczek, J. (1928). Ze studjów nad średniowiecznym Lwowem. Lwów, I Związkowa drukarnia we Lwowie. (Pamiętnik Historyczno-prawny / red. P.Dąbkowskiego. T.VI, Zesz.3). $113 \mathrm{~s}$.

Sperka, J. (2018). Książę Władysław Opolczyk wobec Lwowa. Княжа доба: історія і культура / ред. В. Александрович. Львів, 12. 113-160.

Spież, J. A. (2016). Święty Dominik. Poznań, Wydawnictwo «W drodze», 2016. 104 s.

Vetera Monumenta Poloniae et Lithuaniae (1860), ed. A. Theiner. Roma, Typis Vaticanis, 1860. T. I (1217-1409). $788 \mathrm{p}$.

Voytovich, L. (2016). Korol Danylo Romanovych: davni i moderni napryamy falsifikatsiyi portretu. Korol Danylo Romanovych: kulturna i derzhavotvorcha spadschyna yogo doby / red. M. Bevz, Yu. Lukomskiy. Lviv, «Rastr-7». 12-35. [in Ukrainian].

Vuytsyk, V. S. (1991). Derzhavniy istoryko-kulturnyi zapovidnyk u Lvovi. Lviv, Kamenyar. 175 s. [in Ukrainian].

Wietz, J. K., Bohman P. (1848). Rys historyczny zgromadzeń zakonnych obojej płci wraz z rycerskiemi zakonami i orderami państw. Warszawa, Drukarnia księży pijarów. $258 \mathrm{~s}$.

Zimorovych, B. (2002). Potriynyi Lviv: Leopolis Triplex. Lviv, Tsentr Evropy, 224 s. [in Ukrainian].

Zubrytskyi, D. (2011). Hronika Stavropigiyskogo bratstva. Lviv. 408 s. [in Ukrainian].

Żyła, W. (1923). Kościół i klasztor Dominikanów we Lwowie. Lwów, Drukarnia L. Wiśniewskiego. 76 s.

Статтю надіслано до редколегії 08.07.2021 p. Статтю рекомендовано до друку 15.08.2021 р. 